\title{
Chronic gastritis and gastroduodenal ulcer: a case control study on risk of coexisting duodenal or gastric ulcer in patients with gastritis
}

\author{
P SIPPONEN, K SEPPÄLÄ, M Ä̈̈RYNEN, T HELSKE, AND P KETTUNEN \\ From the Department of Pathology and Internal Medicine, Jorvi Hospital, Espoo, District Hospital of \\ Kuusankoski, Kuusankoski, and Second Department of Medicine, University of Helsinki, Helsinki, Finland
}

SUMMARY Chronic (atrophic) gastritis (AG) is common in active duodenal (DU) and gastric ulcer (GU) disease. In this case control study in consecutive prospective outpatients (571 cases and 1074 controls) who had undergone diagnostic upper gastrointestinal endoscopy and routine biopsies from both antral and body mucosa, we calculated the risk of coexisting active DU and/or GU in different gastritis of the antrum or body and according to grade (superficial gastritis, mild, moderate or severe atrophic gastritis). The risk of coexisting active gastroduodenal ulcer (ulcer in duodenum and/or stomach), as well as the risk of DU or GU, was dependent upon the presence and grade of gastritis in antrum and body mucosa. The risk of coexisting ulcer, as expressed as an age adjusted relative risk (RR) and calculated as odds ratio of gastritis in cases and controls, was significantly increased in the presence of superficial antral and body gastritis $(R R=8 \cdot 5(7 \cdot 0-20 \cdot 0)$ in men; $R R=5 \cdot 8(3 \cdot 3-10 \cdot 2)$ in women), as compared with the risk of ulcer in subjects with histologically normal mucosa $(R R=1)$. The risk of ulcer, and the risk of $\mathrm{GU}$ in particular, increased further with increasing severity of antral gastritis. In such patients with moderate or severe atrophic antral gastritis the RR of coexisting ulcer even exceeded 20 in men and 10 in women $(R R=25 \cdot 6(9 \cdot 0-72 \cdot 7)$ in $\operatorname{men} ; R R=11 \cdot 7$ (5.9-23.0) in women). On the other hand, the RR of ulcer, and the RR of DU in particular, was below 1 in the presence of atrophic gastritis in the gastric body, irrespective of the grade of gastritis in the antrum. We conclude that the type and grade of gastritis strongly predicts the risk of coexisting peptic ulcer, and that the risk of coexisting DU or GU increases with an increase in grade of AG of the antrum but decreases with an increase in grade of AG of the gastric body.

Chronic (atrophic) gastritis is common in active peptic ulcer disease. Antral gastritis occurs in $75-95 \%$ of patients with duodenal ulcer (DU) and nearly always in patients with gastric ulcer (GU) ${ }^{1-4}$ Although the causal relationship between gastritis and ulcer diseases is unclear and controversial, gastritis may play a role in the pathogenesis of DU and GU diseases and may impair the resistance of the gastric mucosa and consequently increase the risk of ulcer. ${ }^{10}$ On the other hand, atrophic gastritis in the gastric body has a negative effect on acid and pepsin secretion, and may subsequently decrease the risk of subjects to contract an active ulcer. ${ }^{.1}$

Gastritis is also common in the general population. It progresses in grade and prevalence with increasing

Address for correspondence: Dr P Sipponen, Department of Pathology, Jorvi Hospital, SF-(1)2740 Espoo, Finland.

Accepted for publication 28 November 1988. age, ${ }^{12-14}$ and occurs as different topographic types that is, as different combinations (phenotypes) of grade and extent of inflammation and atrophy of antral and body mucosa. ${ }^{13-18}$ Little is known about the relationship between peptic ulcer and different types or grades of gastritis. Based on case control design and on consecutive endoscopic series of outpatients with active DU or GU and non-ulcer controls, we calculated the mean risks of coexisting ulcer in patients showing different grades and types of gastritis.

\section{Methods}

\section{PATIENTS}

The patient series (cases) consists of 571 patients with endoscopically verified active ulcer in duodenum and/or stomach. The series was consecutively and 
prospectively collected from outpatients who underwent routine diagnostic upper gastrointestinal endoscopy in 1982-1985 in Jorvi Hospital (Espoo), Kuusankoksi District Hospital (Kuusankoski) and a private clinic (Endoskopia OY; Helsinki, Finland). All patients underwent gastroscopy with routine multiple biopsy specimens from antrum and body. High quality, well oriented specimens from both sites were available in $489(86 \%)$ patients, and only from antrum or body in $59(10 \%)$ and $23(4 \%)$ cases, respectively. Patients with gastric cancer or patients with ulcer in the cardiac region of the stomach were excluded, as were also patients who had ulcer scars without an active ulcer. Correspondingly, patients with superficial ulcerations, such as erosions or acute mucosal lesions without ulcer, were excluded from the patient series but were included in the control series.

The distribution of the patients of the ulcer series according to age, sex and site of the ulcer (the most proximal ulcer in cases with two or more ulcers) are presented in Tables 1 and 2. Ulcer was multiple (two or more ulcers) in $91(16 \%)$ cases.

\section{CONTROLS}

The control series consists of a prospective sample of 1074 non-ulcer patients from the same sources as the ulcer patients, collected consecutively in 1985 . Patients with gastric cancer or ulcer scars were excluded from the control series. The controls were endoscoped as for the ulcer patients. High quality, well oriented biopsy specimens from both sites were

Table 1 Distribution of the ulcer patients into age groups

\begin{tabular}{lccccc}
\hline \multirow{2}{*}{$\begin{array}{l}\text { Age group } \\
\text { (yr) }\end{array}$} & \multicolumn{2}{c}{ Men } & & \multicolumn{2}{c}{ Women } \\
\cline { 2 - 3 } \cline { 5 - 6 } \cline { 5 - 6 } & $n$ & $(\%)$ & & $n$ & $(\%)$ \\
\hline $20-39$ & 60 & $(18 \cdot 3)$ & & 21 & $(8 \cdot 6)$ \\
$40-49$ & 76 & $(23 \cdot 2)$ & & 40 & $(16 \cdot 5)$ \\
$50-59$ & 93 & $(28 \cdot 4)$ & & 53 & $(21 \cdot 8)$ \\
$60-69$ & 57 & $(17 \cdot 4)$ & & 56 & $(23 \cdot 0)$ \\
$70-$ & 42 & $(12 \cdot 8)$ & & 73 & $(30 \cdot 0)$ \\
Total & 328 & $(100)$ & & 243 & $(100)$ \\
\hline
\end{tabular}

Table 2 Distribution of the non-ulcer controls into age groups

\begin{tabular}{lrllll}
\hline & \multicolumn{2}{c}{ Men } & & \multicolumn{2}{l}{ Women } \\
\cline { 2 - 3 } \cline { 5 - 6 } $\begin{array}{l}\text { Age group } \\
\text { (yr) }\end{array}$ & $n$ & $(\%)$ & & $n$ & $(\%)$ \\
\hline $20-39$ & 145 & $(32 \cdot 2)$ & & 189 & $(30 \cdot 2)$ \\
$40-49$ & 103 & $(22 \cdot 9)$ & & 109 & $(17 \cdot 5)$ \\
$50-59$ & 83 & $(18 \cdot 4)$ & & 124 & $(19 \cdot 8)$ \\
$60-69$ & 64 & $(14 \cdot 2)$ & & 104 & $(16 \cdot 7)$ \\
$70-$ & 55 & $(12 \cdot 2)$ & & 98 & $(15 \cdot 7)$ \\
Total & 450 & $(100)$ & & 624 & $(100)$ \\
\hline
\end{tabular}

available in $996(93 \%)$ cases, only from the antrum in $42(4 \%)$ cases and only from the body in $36(3 \%)$ cases. The distribution of the controls into men and women and into different age groups is presented in Table 3 .

INTERPRETATION OF CHRONIC GASTRITIS Chronic (atrophic) gastritis in antrum and body was interpreted from endoscopic biopsy specimens by using the histological criteria originally presented by Schindler ${ }^{12}$ and modified by Siurala et al ${ }^{1314}$ The criteria correspond with those published by other authors. ${ }^{15}$ The grading was done by one of the authors (PS), as follows: normal (N): normal mucosa. No inflammation, no atrophy; superficial chronic gastritis (S): chronic inflammation without loss of normal glands; mild, moderate or severe (total atrophy) atrophic gastritis (A1, A2, A3, respectively): mild, moderate or severe (total) loss of normal glands; varying degrees of inflammation and metaplasias.

Chronic gastritis has been shown to be an age dependent, progressive process. ${ }^{1-1 \times}$ It begins as a superficial gastritis and progresses stepwise from grade to grade, similar in the antrum and body, and among men and women. ${ }^{10-14}$ Different grades of gastritis are well related to function of the stomach for example, to acid secretion, serum pepsinogen or gastrin levels."

Examples of the different degrees of antral and body gastritis are presented and illustrated elsewhere. ${ }^{14}$

STATISTICAL ANALYSIS

The risk of coexisting gastroduodenal ulcer in different grades and types of gastritis was expressed as a relative risk (RR) and was estimated as a MantelHaenszel estimate $\left(R_{\mathrm{mh}}\right)$ by using the histologically normal stomach as a baseline $(R R=1) .{ }^{14} T$ he $R R_{m h}$ 's

Table 3 Distribution of ulcer patients by sex and their mean ages in relation to location* of the ulcer

\begin{tabular}{|c|c|c|c|c|c|c|c|c|}
\hline \multirow{3}{*}{$\begin{array}{l}\text { Location of } \\
\text { ulcer }\end{array}$} & \multicolumn{4}{|c|}{ Men } & \multicolumn{4}{|c|}{ Women } \\
\hline & \multirow[t]{2}{*}{$n$} & \multirow[t]{2}{*}{$(\%)$} & \multicolumn{2}{|c|}{ Mean age } & \multirow[t]{2}{*}{$n$} & \multirow[t]{2}{*}{$(\%)$} & \multicolumn{2}{|c|}{ Mean age } \\
\hline & & & $y r$ & $(S D)$ & & & $y r$ & $(S D)$ \\
\hline Duodenum & 145 & $(44 \cdot 2)$ & 48 & (13) & 66 & $(27 \cdot 2)$ & 56 & (16) \\
\hline Pylorus & 40 & $(12 \cdot 2)$ & 51 & (12) & 29 & $(11.9)$ & 59 & (13) \\
\hline Prepylorus & 38 & $(11 \cdot 6)$ & 55 & (12) & 30 & $(12 \cdot 3)$ & 59 & (14) \\
\hline Antrum & 12 & $(3 \cdot 7)$ & 55 & (12) & 25 & $(10 \cdot 3)$ & 59 & (17) \\
\hline Angulus & 61 & $(18 \cdot 6)$ & 58 & (12) & 54 & $(22 \cdot 2)$ & 59 & (12) \\
\hline Body & 32 & $(9 \cdot 8)$ & 62 & (12) & 39 & $(16 \cdot 0)$ & 63 & (13) \\
\hline Total & 328 & $(100)$ & 53 & (13) & 243 & $(100)$ & 59 & (14) \\
\hline
\end{tabular}

*The most proximal ulcer in cases with two or multiple ulcers. 


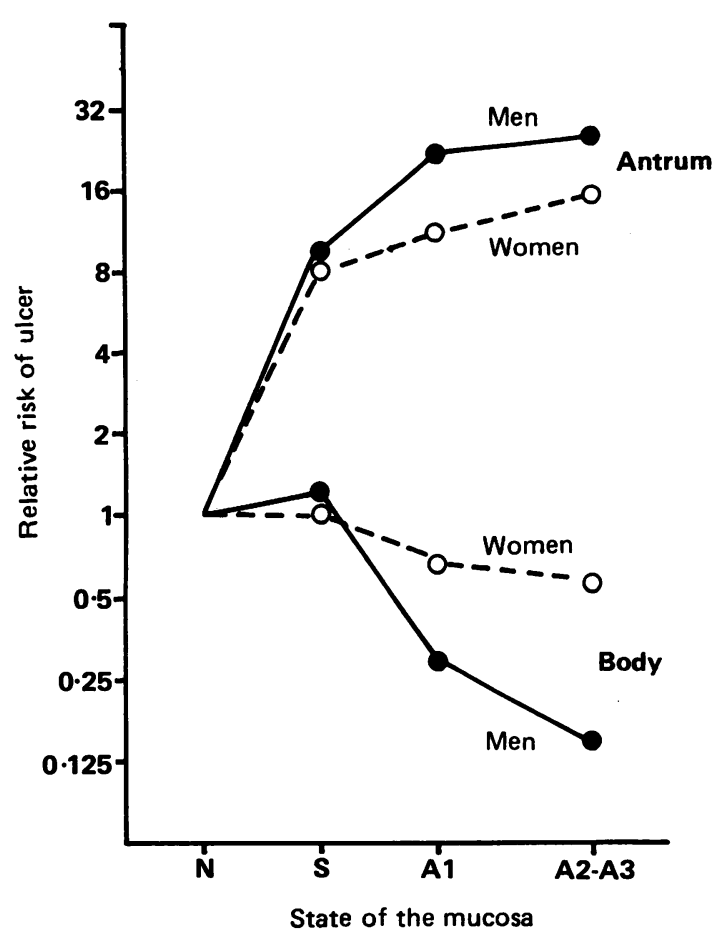

Figure Mean relative risks of duodenal or gastric ulcer in men and women with different grades of chronic gastritis in antrum and body. The risks are adjusted for age and for gastritis on the contralateral site of the stomach (in approximation of the risks of ulcer in antral gastritis, the gastritis in gastric body mucosa is included as a confounding factor, and vica versa). $N=$ normal mucosa, $S=$ superficial gastritis, $A 1=$ mild atrophic gastritis, $A 2-A 3=$ moderate or severe atrophic gastritis.

were adjusted for age by stratification of the cases and controls to age groups as shown in Tables 1 and 2 . The calculations of the age adjusted $R R_{m h}$ 's in antrum or body gastritis were further performed with (Figure) and without (Tables 4-6, 8) inclusion of gastritis on the contralateral side of the stomach as a confounding factor. Differences and trends in the estimated risks, as well as the heterogeneity and trends of the risks over the stratified age strata, were calculated and tested as suggested by Breslow and Day. ${ }^{19}$ The $95 \%$ confidence intervals (CI95) of the relative risks were calculated and are presented as test based limits. ${ }^{19}$

\section{Results}

The relative risks $\left(\mathrm{RR}_{\mathrm{mh}}\right)$ of coexisting ulcer in the different grades of antral and body gastritis were calculated by (i) inclusion of all cases with duodenal and/or gastric ulcer ('gastroduodenal ulcer'; $n=571$ ) into the analysis and, (ii) by separation of subgroups of typical 'duodenal ulcer' (DU, ulcer in duodenal
Table 4 Age adjusted relative risk ( $\left.R R_{\mathrm{mh}}\right)$ of duodenal or gastric ulcer in men with different grades of chronic (atrophic) gastritis in antral or body mucosa

\begin{tabular}{|c|c|c|c|c|c|}
\hline & \multicolumn{4}{|c|}{ State of antral mucosa } & \multirow[b]{2}{*}{ Total } \\
\hline & $N$ & $S$ & $A 1$ & $A 2-A 3$ & \\
\hline $\begin{array}{l}\text { Cases } \\
\text { Controls } \\
\text { Total }\end{array}$ & $\begin{array}{r}15 \\
184 \\
199\end{array}$ & $\begin{array}{l}197 \\
196 \\
393\end{array}$ & $\begin{array}{l}63 \\
33 \\
96\end{array}$ & $\begin{array}{l}42 \\
19 \\
61\end{array}$ & $\begin{array}{l}317 \\
432 \\
749\end{array}$ \\
\hline $\begin{array}{l}\mathrm{RR}_{\mathrm{mh}} \\
\chi^{2} \\
\text { Significance } \\
\text { C195 } \\
\text { Test for heterogeneity: } \chi^{2}\end{array}$ & $\begin{array}{l}1 \cdot 0 \\
2\end{array}$ & $\begin{array}{l}11 \cdot 7 \\
97 \cdot 86 \\
\mathrm{p}<0 \cdot 001 \\
7 \cdot 2-19 \cdot 9 \\
4 \cdot 78(\mathrm{NS})\end{array}$ & $\begin{array}{l}22 \cdot 2 \\
87 \cdot 12 \\
\mathrm{p}<0 \cdot 001 \\
11 \cdot 7-42 \cdot 2 \\
1 \cdot 52(\mathrm{NS})\end{array}$ & $\begin{array}{l}18 \cdot 8 \\
65 \cdot 30 \\
p<0 \cdot 001 \\
29 \cdot 4-37 \cdot 7 \\
6 \cdot 03(\mathrm{NS})\end{array}$ & \\
\hline
\end{tabular}

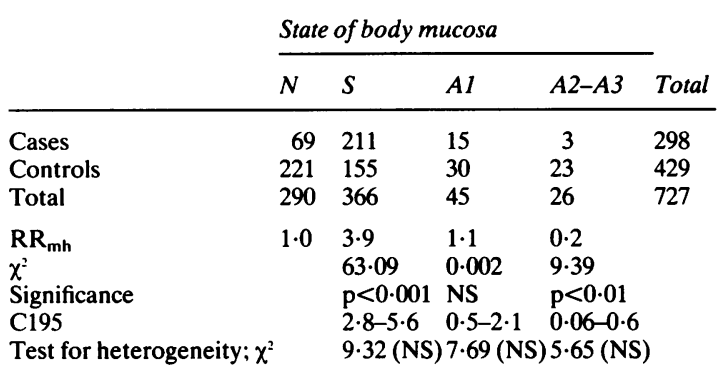

Global test of $\mathrm{H}_{\mathrm{o}}: \chi^{2}=86.41(\mathrm{p}<0 \cdot 001)$.

Test for trend: $\chi^{2}=1 \cdot 72(\mathrm{NS})$.

$\mathrm{N}=$ normal mucosa; $\mathrm{S}=$ superficial gastritis; $\mathrm{A} 1, \mathrm{~A} 2, \mathrm{~A} 3=$ mild, moderate, or severe atrophic gastritis, respectively.

C195 $=95 \%$ confidence interval of the $R R$.

Table 5 Age adjusted relative risk $\left(R R_{\mathrm{mh}}\right)$ of duodenal and gastric ulcer in men and women with superficial $(S)$ or atrophic body gastritis (A1-A3). Normal body mucosa $(N)$ is the baseline $(R R=1)$

\begin{tabular}{|c|c|c|c|c|}
\hline $\begin{array}{l}\text { Sex/state of } \\
\text { body mucosa }\end{array}$ & $\begin{array}{l}\text { Cases/ } \\
\text { controls }\end{array}$ & $\begin{array}{l}\text { Relative risk } \\
\left(R R_{\mathrm{mh}} ;\right. \\
(C 195))\end{array}$ & Significance & $\begin{array}{l}\text { Heterogeneity/ } \\
\text { trend between } \\
\text { age strata }\end{array}$ \\
\hline \multicolumn{5}{|c|}{ Duodenal ulcer* } \\
\hline \multicolumn{5}{|c|}{ Men } \\
\hline $\mathrm{N}$ & $37 / 221$ & $1 \cdot 0$ & & \\
\hline S & $98 / 155$ & $3 \cdot 6(2 \cdot 4-5 \cdot 3)$ & $\mathrm{p}<0.001$ & $\mathrm{p}<0.01 / \mathrm{NS}$ \\
\hline A1-A3 & $4 / 53$ & $0.3(0.1-0.8)$ & $\mathrm{p}<0.01$ & NS/NS \\
\hline \multicolumn{5}{|l|}{ Women } \\
\hline $\mathbf{N}$ & $22 / 289$ & 1.0 & & \\
\hline $\mathrm{S}$ & $42 / 218$ & $2 \cdot 1(1 \cdot 2-3 \cdot 5)$ & $\mathrm{p}<0.05$ & NS/NS \\
\hline A1-A3 & $2 / 96$ & $0.3(0 \cdot 1-0.8)$ & $\mathrm{p}<0.01$ & NS $/ P<0.05$ \\
\hline \multicolumn{5}{|l|}{ Gastric ulcer $\dagger$} \\
\hline \multicolumn{5}{|l|}{ Men } \\
\hline $\mathrm{N}$ & $12 / 221$ & $1 \cdot 0$ & & \\
\hline S & $58 / 155$ & $5 \cdot 4(2 \cdot 9-10 \cdot 0)$ & $p<0.001$ & NS/NS \\
\hline A1-A3 & $11 / 53$ & $3 \cdot 1(1 \cdot 3-7 \cdot 4)$ & $p<0.05$ & NS/NS \\
\hline \multicolumn{5}{|l|}{ Women } \\
\hline $\mathbf{N}$ & $8 / 289$ & $1 \cdot 0$ & & \\
\hline S & $45 / 218$ & $6 \cdot 2(3 \cdot 0-12 \cdot 7)$ & $p<0.001$ & NS/NS \\
\hline A1-A3 & $23 / 96$ & $6 \cdot 1(2 \cdot 8-13 \cdot 4)$ & $p<0.001$ & NS/NS \\
\hline
\end{tabular}

C195 $=95 \%$ confidence interval of the $R R$.

*Duodenal ulcer cases; $\uparrow$ Cases with ulcer in angular area or in gastric body. 
Table 6 Age adjusted relative risk $\left(R R_{\mathrm{mh}}\right)$ of duodenal or gastric ulcer in women with different grades of chronic gastritis in the antrum or body mucosa

\begin{tabular}{|c|c|c|c|c|c|}
\hline & \multicolumn{4}{|c|}{ State of antral mucosa } & \multirow[b]{2}{*}{ Total } \\
\hline & $N$ & $S$ & $A 1$ & $A 2-A 3$ & \\
\hline Cases & 17 & 134 & 58 & 22 & 231 \\
\hline Controls & 271 & 246 & 61 & 28 & 606 \\
\hline Total & 288 & 380 & 119 & 50 & 837 \\
\hline $\mathrm{RR}_{\mathrm{mh}}$ & $1 \cdot 0$ & $7 \cdot 2$ & 9.9 & $8 \cdot 5$ & \\
\hline$\chi^{2}$ & & $65 \cdot 38$ & $61 \cdot 01$ & $27 \cdot 74$ & \\
\hline Significance & & $\mathrm{p}<0.001$ & $\mathrm{p}<0.001$ & $\mathrm{p}<0.001$ & \\
\hline $\mathrm{C} 195$ & & $4 \cdot 5-11 \cdot 5$ & $5 \cdot 6-17 \cdot 4$ & $4 \cdot 1-17 \cdot 9$ & \\
\hline Test for heterogeneity; $\chi$ & & $\begin{array}{l}9.73 \\
(p<0.05)\end{array}$ & $\begin{array}{l}8 \cdot 16 \\
(\mathrm{NS})\end{array}$ & $\begin{array}{l}11 \cdot 16 \\
(p<0.05)\end{array}$ & \\
\hline
\end{tabular}

\begin{tabular}{|c|c|c|c|c|c|}
\hline & \multicolumn{4}{|c|}{ State of body mucosa } & \multirow[b]{2}{*}{ Total } \\
\hline & $N$ & $S$ & $A I$ & $A 2-A 3$ & \\
\hline Cases & 57 & 138 & 16 & 7 & 214 \\
\hline Controls & 289 & 218 & 47 & 49 & 603 \\
\hline Total & 342 & 356 & 63 & 56 & 817 \\
\hline \multirow{5}{*}{$\begin{array}{l}\mathrm{RR}_{\mathrm{mh}} \\
\chi^{2} \\
\text { Significance } \\
\text { C195 } \\
\text { Test for heterogeneity; } \chi\end{array}$} & $1 \cdot 0$ & $2 \cdot 7$ & $1 \cdot 1$ & $0 \cdot 4$ & \\
\hline & & $25 \cdot 61$ & 0.04 & 3.65 & \\
\hline & & $p<0.0001$ & $1 \mathrm{NS}$ & NS & \\
\hline & & $1 \cdot 8-3 \cdot 9$ & $0 \cdot 6-2 \cdot 2$ & $0.01-1.2$ & \\
\hline & & $4 \cdot 23(\mathrm{NS})$ & $1.76(\mathrm{NS})$ & $7 \cdot 37$ (NS) & \\
\hline \multicolumn{5}{|c|}{$\begin{array}{l}\text { Global test of } \mathrm{H}_{\mathrm{o}}: \chi^{2}=44 \cdot 21(\mathrm{p}<0 \cdot 001) \text {. } \\
\text { Test for trend: } \chi^{2}=0 \cdot 40(\mathrm{NS}) \text {. }\end{array}$} & \\
\hline
\end{tabular}

$\mathrm{N}=$ normal mucosa; $\mathrm{S}=$ superficial gastritis; $\mathrm{A} 1, \mathrm{~A} 2, \mathrm{~A} 3$ =mild, moderate, or severe atrophic gastritis, respectively.

C195 $=95 \%$ confidence interval of the RR.

bulb; $\mathrm{n}=211$ ) and 'gastric ulcer' (GU, ulcer in angular area or in gastric body; $n=186$ ).

GASTRODUODENAL ULCER

The $\mathrm{RR}_{\mathrm{mh}}$ of coexisting gastroduodenal ulcer (all cases with ulcer either in duodenum and/or stomach) in the different grades of antral and body gastritis are presented in Tables 4 and 6 and in the Figure. In Tables 4 and 6 the mean risks are adjusted for age alone whereas in the Figure the data are also standardised to take account of coexisting antral gastritis in examining the risks associated with body gastritis, and vica versa.

In comparison with the risk of coexisting active ulcer in subjects with normal antral mucosa $(R R=1)$, the mean risk of gastroduodenal ulcer was highly significantly above the baseline level $(R R=1)$ in subjects who showed antral gastritis (Figure). This risk was increased already in subjects with superficial antral gastritis (grade $S ; R_{\text {mh }} 9 \cdot 7(6 \cdot 1-15 \cdot 5)$ in men and $8 \cdot 2(5 \cdot 7-12 \cdot 0)$ in women), and it further linearly increased in both sexes with an increase in grade of antral gastritis: the $\mathbf{R R}_{\mathrm{mh}}$ of ulcer reached levels of $25 \cdot 6(8 \cdot 6-76 \cdot 3)$ and $14 \cdot 8(4 \cdot 4-49 \cdot 3)$, respectively, in men and women who had antral gastritis of grades of A2-A3 (Figure).

The influence of body gastritis on the ulcer risk was opposite to that of antral gastritis. The risk of coexisting ulcer decreased significantly and linearly with an increase in grade of body gastritis (Figure): the mean $R_{R_{m h}}$ 's of ulcer in men with superficial body gastritis (S) or with advanced atrophic body gastritis (A2-A3) were $1.4(1 \cdot 2-1 \cdot 6)$ and $0.1(0.04$ $0 \cdot 4)$, respectively. The corresponding risks in women were $1.02(1 \cdot 01-1.03)$ and $0.6(0.4-0 \cdot 8)$ (Figure).

The age adjusted $\mathrm{RR}_{\mathrm{mh}}$ 's of coexisting active ulcer in subjects with different combinations (phenotypes) of antral and body gastritis, in comparison with risk of ulcer in the presence of a normal stomach (phenotype $\mathrm{N} / \mathrm{N} ; \mathrm{RR}=1$ ), are shown in Table 7 . The ulcer risk in both sexes was clearly and significantly increased in most of the phenotypes, although some important differences existed. We emphasise the following three observations (Table 7).

First, the atrophic antral gastritis (A1-A3) that coexisted with non-atrophic body mucosa ( $\mathrm{N}$ or $\mathrm{S}$ ) was the phenotype in which the risk of ulcer was highest: the ulcer risk in subjects with phenotype A1A3/S exceeded 20 for men and 10 for women. Second, irrespective of the grade of gastritis of the antrum, the presence of even mild atrophic gastritis (A1) in gastric body mucosa significantly decreased the risk of coexisting ulcer to levels that were indistinguishable from the baseline $(R R=1)$. Third, in comparison with phenotype $\mathrm{N} / \mathrm{N}$, the risk of ulcer in all phenotypes of gastritis tended to be higher in men than women.

DUODENAL AND GASTRIC ULCER

The estimates for the age adjusted relative risks, separately for co-existing DU (active ulcer in duodenal bulb) or GU (active angular or high gastric ulcer), in patients with antral or body gastritis are presented in Tables 5 and 8.

The risks of both DU and GU in both sexes were highly significantly higher in the presence of superficial gastritis (S) in the antrum than in the presence of histologically normal antrum (Table 8 ). There were, however, some differences between DU and GU.

First, with increase in grade of antral gastritis from $\mathrm{S}$ to $\mathrm{A} 1-\mathrm{A} 3$ the mean $\mathrm{RR}_{\mathrm{mh}}$ of coexisting GU greatly increased; this risk exceeded 30 in men and 20 in women if the patient had atrophic gastritis (A1-A3) in the antrum. The risk of coexisting DU did not show such a trend, however (Table 8). Second, with increase in grade of chronic body gastritis from $\mathrm{S}$ to 
Table 7 Age adjusted relative risk $\left(R R_{\mathrm{mh}}\right)$ of duodenal or gastric ulcer in men and women with different phenotypes and grades of chronic (atrophic) gastritis. Normal stomach $(N / N)$ is the baseline category $(R R=1)$

\begin{tabular}{|c|c|c|c|c|}
\hline $\begin{array}{l}\text { Sex/state of mucosa; } \\
\text { antrum/body }\end{array}$ & Cases/controls & Relative risk $\left(R R_{\mathrm{mh}} ;(C 195)\right)$ & Significance & $\begin{array}{l}\text { Heterogeneity/trend } \\
\text { between age strata }\end{array}$ \\
\hline \multicolumn{5}{|l|}{ Men } \\
\hline $\mathrm{N} / \mathrm{N}$ & $13 / 154$ & $1 \cdot 0$ & & \\
\hline $\mathrm{S} / \mathrm{N}$ & $37 / 44$ & $8 \cdot 4(4 \cdot 3-16 \cdot 2)$ & $\mathrm{p}<0.001$ & NS/NS \\
\hline $\mathrm{S} / \mathrm{S}$ & $135 / 119$ & $8 \cdot 5(7 \cdot 0-20 \cdot 0)$ & $\mathrm{p}<0.001$ & NS/NS \\
\hline S/A1 & $5 / 15$ & $2 \cdot 4(0 \cdot 7-9 \cdot 1)$ & NS & NS/NS \\
\hline $\mathrm{S} / \mathrm{A} 1-\mathrm{A} 3$ & $11 / 22$ & $2 \cdot 1(0 \cdot 6-6 \cdot 8)$ & NS & NS/NS \\
\hline $\mathrm{A} 1 / \mathrm{N}$ & $12 / 6$ & $25 \cdot 6(9 \cdot 0-72 \cdot 7)$ & $\mathrm{p}<0.001$ & NS/NS \\
\hline $\mathrm{A} 1 / \mathrm{S}$ & $42 / 15$ & $23 \cdot 2(10 \cdot 7-50 \cdot 0)$ & $\mathrm{p}<0.001$ & NS/NS \\
\hline $\mathrm{A} 1 / \mathrm{A} 1-\mathrm{A} 3$ & $4 / 10$ & $3 \cdot 1(0 \cdot 7-14 \cdot 0)$ & NS & NS/NS \\
\hline $\mathrm{A} 2-\mathrm{A} 3 / \mathrm{S}$ & $27 / 9$ & $16 \cdot 6(7 \cdot 1-38 \cdot 8)$ & $\mathrm{p}<0.001$ & NS/NS \\
\hline $\mathrm{A} 1-\mathrm{A} 3 / \mathrm{N}$ & $14 / 9$ & $15 \cdot 9(6 \cdot 1-41 \cdot 2)$ & $\mathrm{p}<0.001$ & NS/NS \\
\hline $\mathrm{A} 1-\mathrm{A} 3 / \mathrm{S}$ & $69 / 24$ & $21 \cdot 0(10 \cdot 8-40 \cdot 9)$ & $\mathrm{p}<0.001$ & NS/NS \\
\hline $\mathrm{A} 1-\mathrm{A} 3 / \mathrm{A} 1-\mathrm{A} 3$ & $11 / 17$ & $6 \cdot 0(2 \cdot 3-15 \cdot 4)$ & $\mathrm{p}<0.001$ & $\mathrm{p}<0 \cdot 05 / \mathrm{NS}$ \\
\hline \multicolumn{5}{|l|}{ Women } \\
\hline $\mathrm{N} / \mathrm{N}$ & $14 / 218$ & $1 \cdot 0$ & & \\
\hline $\mathrm{S} / \mathrm{N}$ & $26 / 55$ & $6 \cdot 3(3 \cdot 3-11 \cdot 7)$ & $\mathrm{p}<0.001$ & NS/NS \\
\hline $\mathrm{S} / \mathrm{S}$ & $81 / 159$ & $5 \cdot 8(3 \cdot 3-10 \cdot 2)$ & $\mathrm{p}<0 \cdot 001$ & NS/NS \\
\hline S/A 1 & $7 / 15$ & $4 \cdot 5(1 \cdot 6-12 \cdot 5)$ & $\mathrm{p}<0.05$ & NS/NS \\
\hline S/A2-A3 & $4 / 11$ & $3 \cdot 2(1 \cdot 0-10 \cdot 1)$ & NS & NS/NS \\
\hline $\mathrm{A} 1 / \mathrm{S}$ & $40 / 31$ & $11 \cdot 7(5 \cdot 9-23 \cdot 0)$ & $\mathrm{p}<0.001$ & NS/NS \\
\hline A $1 / A 1$ & $6 / 14$ & $3 \cdot 7(1 \cdot 1-11 \cdot 9)$ & NS & NS/NS \\
\hline $\mathrm{A} 1 / \mathrm{A} 1-\mathrm{A} 3$ & $8 / 22$ & $3 \cdot 3(1 \cdot 2-9 \cdot 0)$ & $\mathrm{p}<0.05$ & $\mathrm{p}<0.05 / \mathrm{NS}$ \\
\hline $\mathrm{A} 2-\mathrm{A} 3 / \mathrm{S}$ & $13 / 14$ & $7 \cdot 9(3 \cdot 2-19 \cdot 2)$ & $\mathrm{p}<0.001$ & NS/NS \\
\hline $\mathrm{A} 1-\mathrm{A} 3 / \mathrm{N}$ & $6 / 9$ & $6 \cdot 5(2 \cdot 2-19 \cdot 0)$ & $\mathrm{p}<0 \cdot 01$ & NS/NS \\
\hline $\mathrm{A} 1-\mathrm{A} 3 / \mathrm{S}$ & $53 / 45$ & $10 \cdot 8(5 \cdot 7-20 \cdot 3)$ & $\mathrm{p}<0.001$ & NS/NS \\
\hline $\mathrm{A} 1-\mathrm{A} 3 / \mathrm{A} 1-\mathrm{A} 3$ & $12 / 32$ & $3 \cdot 3(1 \cdot 3-8 \cdot 7)$ & $\mathrm{p}<0.05$ & NS/NS \\
\hline
\end{tabular}

Normal mucosa: $\mathrm{S}=$ superficial gastritis; $\mathrm{A} 1, \mathrm{~A} 2, \mathrm{~A} 3$ =mild, moderate, or severe atrophic gastritis, respectively.

$\mathrm{C} 195=95 \%$ confidence interval of the RR.

Table 8 Age adjusted relative risk $\left(R R_{\mathrm{mh}}\right)$ of duodenal and gastric ulcer in men and women with superficial $(S)$ or atrophic antral gastritis $(A I-A 3)$. Normal body mucosa $(N)$ is the baseline $(R R=1)$

\begin{tabular}{|c|c|c|c|c|}
\hline Sex/state of antral mucosa & Cases/controls & Relative risk $\left(R R_{\mathrm{mh}} ;(C 195)\right)$ & Significance & $\begin{array}{l}\text { Heterogeneity/trend } \\
\text { between age strata }\end{array}$ \\
\hline \multicolumn{5}{|l|}{ Duodenal ulcer* } \\
\hline \multicolumn{5}{|l|}{ Men } \\
\hline $\mathrm{N}$ & $5 / 184$ & $1 \cdot 0$ & & \\
\hline $\mathrm{S}$ & $110 / 196$ & $16 \cdot 2(7 \cdot 4-35 \cdot 3)$ & $\mathrm{p}<0.001$ & NS/NS \\
\hline A $1-A 3$ & $28 / 52$ & $18 \cdot 4(9 \cdot 3-36 \cdot 2)$ & $\mathrm{p}<0.001$ & NS/NS \\
\hline \multicolumn{5}{|l|}{ Women } \\
\hline $\mathrm{N}$ & $6 / 271$ & 1.0 & & \\
\hline S & $39 / 246$ & $5 \cdot 7(2 \cdot 8-11 \cdot 8)$ & $\mathrm{p}<0 \cdot 001$ & NS/NS \\
\hline A $1-A 3$ & $17 / 89$ & $4 \cdot 8(2 \cdot 1-10 \cdot 7)$ & $\mathrm{p}<0 \cdot 001$ & NS/NS \\
\hline \multicolumn{5}{|l|}{ Gastric ulcer $\dagger$} \\
\hline \multicolumn{5}{|l|}{ Men } \\
\hline $\mathrm{N}$ & $4 / 184$ & 1.0 & & \\
\hline $\mathrm{S}$ & $30 / 196$ & $6 \cdot 5(2 \cdot 5-16 \cdot 7)$ & $\mathrm{p}<0.001$ & NS/NS \\
\hline A1-A3 & $55 / 52$ & $32 \cdot 2(15 \cdot 6-66 \cdot 5)$ & $\mathrm{p}<0.001$ & $\mathrm{p}<0 \cdot 05 / \mathrm{NS}$ \\
\hline \multicolumn{5}{|l|}{ Women } \\
\hline $\mathrm{N}$ & $2 / 271$ & $1 \cdot 0$ & & \\
\hline $\mathrm{S}$ & $47 / 246$ & $18 \cdot 4(7 \cdot 2-47 \cdot 2)$ & $\mathrm{p}<0.001$ & NS/NS \\
\hline $\mathrm{A} 1-\mathrm{A} 3$ & $41 / 89$ & $24 \cdot 4(10 \cdot 9-54 \cdot 6)$ & $\mathrm{p}<0.001$ & $\mathrm{p}<0.001 / \mathrm{p}<0.001$ \\
\hline
\end{tabular}

$\mathrm{C} 195=95 \%$ confidence interval of the RR.

*Duodenal ulcer cases: $†$ Cases with ulcer in angular area or in gastric body. 
A1-A3 the risk of DU decreased significantly in both sexes below the baseline level $(R R=1)$, whereas the risk of GU was of same magnitude in both sexes in the presence of S or A1-A3 in the gastric body (Table 5).

\section{Discussion}

The present calculations show that a strong association between chronic gastritis and active peptic ulcer exists. In the presence of gastritis, an active ulcer either in duodenum or stomach was several times more common than expected. Although DU and GU do not occur in fundamentally similar circumstances, both seem to show similar features in relation to gastritis. In comparison with subjects with histologically normal gastric mucosa, the risk and probability of coexisting ulcer was markedly and highly significantly increased in the presence of gastritis, this risk and probability being dependent on grade of gastritis in antrum and body. With regard to these risks, however, antral and body gastritis behaved opposite to each other: the risk of active ulcer rose linearly with an increase in grade of gastritis of the antral mucosa but decreased, again linearly, with an increase in grade of gastritis of the gastric body. The calculations showed that the risk of coexisting ulcer was highest in patients who had atrophic gastritis in the antrum and non-atrophic mucosa in the gastric body - that is, gastritis of the B type. ${ }^{21}$ Active DU or GU appeared over 20 times more common among men with gastritis of this B type than in subjects with histologically normal stomach.

The extremely common occurrence of gastritis in ulcer patients ${ }^{1-y 21}$ and the high risk of coexisting active ulcer in gastritis may suggest that gastritis is causally related to both DU and GU, even though the possibility cannot be excluded that gastritis simply results from the ulcer itself. The present observations on 'dose-response' like relationship between grade of gastritis and general ulcer risk could be, however, considered to support the former possibility. In addition, this is suggested by earlier observations that the healing of ulcer is not accompanied by resolution of the gastritis. ${ }^{37223}$ Furthermore, GU typically develops in the stomach at the distal site of the antrofundal junction where the gastritic and atrophic alterations usually are most extensive. ${ }^{2428}$ These findings may indirectly suggest that gastritis precedes and predisposes to ulcer rather than simply accompanies or follows it.

The negative relationship between active ulcer and body gastritis can be explained by a negative effect of gastritis on capability of the body mucosa to secrete acid and pepsins, and by a consequent decrease in probability of a subject to contract peptic ulcer. Inflammation and atrophy cause a loss of normal acid and pepsinogen secreting elements in the oxyntic mucosa. ${ }^{2 x}$ The acid secretion capacity of the stomach is indeed linearly dependent upon the total mass of parietal cells and upon the number of normal oxyntic glands, ${ }^{29.31}$ and even a mild atrophic gastritis in the gastric body mucosa results in a significant reduction of both basal and stimulated acid secretion."

The opposite relation of atrophic antral and body gastrites to ulcer risks indicates that antral and body gastrites are independent risk factors. The joint risks, that were directly obtained from the calculation of the risks of co-existing ulcer in different phenotypes of antral and body gastrites were, however, not clear multiplicands of the estimated marginal risks, suggesting that antral and body gastrites nevertheless have some interactions as regards the final ulcer risk. Irrespective of the grade of antral gastritis, body gastritis seems to determine this final risk: the $R R_{m h}$ of coexisting ulcer in patients with even mild body atrophy exceeded only slightly and insignificantly the level of the risk seen in subjects with histologically normal stomach. This strong influence of body atrophy on ulcer risk seems to concern DU in particular.

The present calculations showed that a homogeneity in ulcer risks over the age strata exists. Although the relative frequencies of the DU and GU cases were very dissimilar in young and old age groups of the present series (Table 3), the estimated relative risks of coexisting ulcer did not show, in any of the categories of gastritis, any clear trends or heterogeneity by age (Table 4-8), suggesting that chronic gastritis per se is similarly associated with ulcer disease in general. This may further indicate that the DU particularly affects subjects in the early stages of the gastritic progression, whereas GU is more likely to affect subjects in advanced and later phases of this process. This view is supported by the present observations that the risk of coexisting GU, but not of DU, tends to increase with an increase in grade of the antral gastritis, and that the risk of coexisting DU in particular tends to decrease with an increase in grade of the body gastritis. Higher mean and median ages of GU patients compared with those of DU patients may also support this conclusion.

The present study is based on cross section analysis of consecutive routine diagnostic outpatient endoscopies. The biopsy specimens were interpreted by one pathologist but the endoscopies were performed by several endoscopists. This may cause some variability in site of the biopsy specimens from the stomach. This bias, however, probably affects ulcer patients and controls, and possibly is of minor significance. Some more serious biases may, however, emerge from obvious differences in the nature of gastritis in ulcer patients and controls. A limited 
number of biopsy specimens may in histology overemphasise the grade of gastritis in severely patchy lesions as often is the case in gastritis in ulcer patients, in contrast with non-ulcer controls in whom gastritis is more commonly diffuse. An underestimation of the risks may, on the other hand, emerge by inclusion of all ulcer patients into the analysis - for example, ulcer patients with significant NSAID ingestion may increase the proportion of cases with histologically normal stomach among the ulcer patients, thus again decreasing the estimated risks of ulcer in subjects with gastritis.

In spite of the above reservations and threatening biases, the present results may have some practical implications: a coexisting active peptic ulcer disease, either duodenal or gastric, might be improbable and rare if the patient has histologically normal stomach or advanced atrophic gastritis in gastric body. On the other hand, the ulcer disease may be possible if a clear cut antral gastritis is present, and if this gastritis is accompanied by non-atrophic gastric body mucosa.

The cumulative risk of active ulcer may follow these similar guidelines, presuming that gastritis is not a simple result from ulcer itself. Thus, the risk of coexisting ulcer, the short term cumulative risk of active peptic ulcer could be very low in subjects in whom the stomach is histologically normal, but considerable if the subject has chronic antral gastritis. As the mean annual transition risk of a subject to move from normal to a pool of subjects with superficial gastritis, or further from the superficial gastritis pool to a pool of subjects with atrophic gastritis, is between 1 and $2 \%$ of the general population, ${ }^{17}$ it would be rather improbable that a person would contract gastritis and subsequent DU or GU within the next few years if his/her stomach is now histologically normal.

More positive conclusions on cumulative ulcer risks can be suggested if atrophic gastritis is present in the gastric body. Because the body gastritis is an irreversible lesion, ${ }^{17}$ the cumulative, even a late risk of peptic ulcer, and of DU in particular, would be low or even non-existent if a clear cut advanced atrophic gastritis is present in the gastric body.

The above conclusions may suggest that patients can be indeed divided into different categories of ulcer risk on the grounds of absence or presence of different types and grades of gastritis in the stomach as is proposed by Baron ${ }^{31}$ or by Samloff et al on the grounds of acid secretion or serum pepsinogen levels. ${ }^{32}$

The study was supported from grants from the Yrjö Jahnsson Foundation, Helsinki, Finland.

\section{References}

1 Mackay IR, Hislop IG. Chronic gastritis and gastric ulcer. Gut 1966; 7: 228-33.

2 Schrager J, Spink R, Mitra S. The antrum in patients with duodenal and gastric ulcers. Gut 1967; 8: 497-508.

3 Gear MWL, Truelove SC, Whitehead R. Gastric ulcer and gastritis. Gut 1971; 12: 639-45.

4 Meister H, Holubarsch Ch, Haferkamp O, Schlag P. Herfarth Ch. Gastritis, intestinal metaplasia, and dysplasia versus benign ulcer in stomach and duodenum and gastric carcinoma. A histotopographic study. Pathol Res Pract 1979; 164: 259-69.

5 Overgaard Nielsen H, Munoz JD, Kronborg O, Andersen D. The antrum in duodenal ulcer patients. Scand J Gastroenterol 1981; 16: 491-3.

6 Earlam RJ, Amerigo J, Kakavoulis T, Pollock DJ. Histological appearances of oesophagus, antrum and duodenum and their correlation with symptoms in patients with a duodenal ulcer. Gut 1985; 26: 95-100.

7 Meikle DD, Taylor KB, Truelove SC, Whitehead R. Gastritis, duodenitis, and circulating levels of gastrin in duodenal ulcer before and after vagotomy. Gut 1976; 17: 719-28.

8 Cheli R, Giacosa A. Duodenal ulcer and chronic gastritis. Endoscopy 1986; 18: 125-6.

9 Hui W-M, Lam A-K, Ho J, et al. Chronic antral gastritis in duodenal ulcer. Natural history and treatment with prostaglandin E1. Gastroenterology 1986; 91: 1095-101.

10 Ippoliti A, Walsh J. Newer concepts in the pathogenesis of peptic ulcer disease. Surg Clin North Am 1976; 56: 1479-90.

11 Varis K, Ihamäki T, Härkönen M, Samloff IM, Siurala M. Gastric morphology, function and immunology in first-degree relatives of probands with pernicious anaemia and controls. Scand J Gastroenterol 1979; 14: 129-39.

12 Schindler R. Gastritis. New York: Grune \& Stratton, 1947.

13 Siurala M, Isokoski M, Varis K, Kekki M. Prevalence of gastritis in a rural population. Scand J Gastroenterol 1968; 3: 211-23.

14 Siurala M, Kivilaakso E, Sipponen P. Gastritis. In: Demling L, Domschke S, eds. Klinische Gastroenterologie. Band I. Stuttgart: Georg Thieme Verlag, 1984: 321-37.

15 Whitehead R, Truelove SC, Gear MWL. The histological diagnosis of chronic gastritis in fibreoptic biopsy specimens. J Clin Pathol 1972; 25: 1-11.

16 Hovinen E, Kekki M, Kuikka S. A theory of the stochastic dynamic model building for chronic progressive disease process with application to chronic gastritis. J Theor Biol 1976; 57: 131-52.

17 Siurala M, Varis K, Kekki M. New aspects on epidemiology, genetics, and dynamics of chronic gastritis. Front Gastrointest Res 1980; 6: 148-66.

18 Kekki M, Sipponen P, Siurala M. Progression of antral and body gastritis in patients with active and healed duodenal ulcer and duodenitis. Scand J Gastroenterol 1984; 19: 382-8.

19 Breslow NE, Day NE. Statistical methods in cancer research. Volume I. The analysis of case-control studies. Lyon: IARC Scientific Publications No 32, 1980: 122-59. 
20 Strickland RG, MacKay IR. A reappraisal of the nature and significance of chronic atrophic gastritis. Dig Dis Sci 1973; 18: $426-40$

21 Moore SC, Malagelada J-R, Shorter RG, Zinsmeiter AR. Interrelationship among gastric mucosal morphology, secretion, and motility in peptic ulcer disease. Dig Dis Sci 1986; 31: 673-83.

22 Piper DW, Greig M, Coupland GAE, Hobbin E, Shinner J. Factors relevant to the prognosis of chronic gastric ulcer. Gut 1975; 16: 714-8.

23 Maaroos H-I, Salupere V. Uibo R, Kekki M, Sipponen P. Seven-year follow-up study of chronic gastritis in gastric ulcer patients. Scand J Gastroenterol 1985; 20: 198-204.

24 Oi M, Ito Y, Kumagai F, et al. A possible duel control mechanism in the origin of peptic ulcer. A study on ulcer location as affected by mucosa and musculature. Gastroenterology 1969; 57: 280-93.

25 Stemmermann G. Haenszel W, Locke F. Epidemiologic pathology of gastric ulcer and gastric carcinoma among Japanese and Hawaii. J Natl Cancer Inst 1977; 58: 13-9.

26 Kimura K. Chronological transition of the fundic pyloric border determined by stepwise biopsy of the lesser and greater curvatures of the stomach. Gastroenterology 1972; 63: 584-92.

27 Trier JS. Morphology of the gastric mucosa in patients with ulcer diseases. Am J Dig Dis 1976; 21: 138-40.

28 Stadelmann O. Elster K. Stolte M, et al. The peptic gastric ulcer - Histotopographic and functional investigations. Scand J Gastroenterol 1971; 6: 613-23.

29 Cheng FCY, Lam SK, Omg GB. Maximal acid output to graded doses of pentagastrin and its relation to parietal cell mass in Chinese patients with duodenal ulcer. Gut 1977; 18: 827-32.

30 Card WI, Marks IN. The relationship between the acid output of the stomach following 'maximal' histamine stimulation and the parictal cell mass. Clin Sci 1960; 19: $147-63$.

31 Baron JH. Pathophysiology of gastric acid and pepsin secretion. In: Domschke W. Wormsley KG, eds. Magen und Magenkrankheiten. New York: Georg Thieme Verlag, 1981: 131-49.

32 Samloff IM, Stemmermann GN, Heilbrun LK, Nomura A. Elevated serum pepsinogen I and II levels differ as risk factors for duodenal ulcer and gastric ulcer. Gastroenterology 1986; 90: 570-6. 